\title{
Nitrogen efficiency of wheat: Genotypic and environmental variation and prospects for improvement
}

\author{
Peter B. Barraclough ${ }^{\mathrm{a}, *}$, Jonathan R. Howarth ${ }^{\mathrm{a}}$, Janina Jones ${ }^{\mathrm{a}}$, Rafael Lopez-Bellido ${ }^{\mathrm{b}}$, \\ Saroj Parmar ${ }^{\mathrm{a}}$, Caroline E. Shepherd ${ }^{\mathrm{a}}$, Malcolm J. Hawkesford ${ }^{\mathrm{a}}$ \\ a Plant Science Department, Rothamsted Research, West Common, Harpenden, Hertfordshire, AL5 2JQ UK \\ b Departamento de Ciencias y Recursos Agrícolas y Forestales, Universidad de Córdoba, Edificio C4 “Celestino Mutis”, Ctra. 14071 Córdoba, Spain
}

\section{A R T I C L E I N F O}

\section{Article history:}

Received 14 October 2009

Received in revised form 21 January 2010

Accepted 22 January 2010

\section{Keywords:}

Crop nutrition

Cultivar

Efficiency

Nitrogen

Quality

Uptake

Utilization

Variety

Wheat

Yield

\begin{abstract}
A B S T R A C T
Winter wheat (Triticum aestivum L.) was grown for 4 years in multi-factorial field trials at Rothamsted, southern England. Thirty nine elite commercial cultivars (primarily short-straw) were grown including those released in the UK over a 25-year period, a selection of continental varieties, and three older, tall varieties. Varieties spanned the quality spectrum from 'bread' to 'feed'. The crops were given ammonium nitrate at five rates in the range $0-350 \mathrm{~kg}-\mathrm{N} / \mathrm{ha}$ as a 3 -way split. The aim was to quantify the genotypic variation in total nitrogen uptake by grain and straw (total-Nup), and in nitrogen utilization efficiency for grain yield (grain yield per unit of $\mathrm{N}$ taken up) (grain-NutE). Depending on treatment, grain yield ranged from 2.1 to $11.8 \mathrm{t}$ /ha (85\% DM), grain \%N from $1.1 \%$ to $2.8 \%$ (in DM), total-Nup from 31 to $264 \mathrm{~kg}-\mathrm{N} / \mathrm{ha}$, and grain-NutE from 27 to $77 \mathrm{~kg}-\mathrm{DM} / \mathrm{kg}-\mathrm{N}$. There were significant varietal differences in total N-uptake and grain-NutE both between 'tall' and 'short' varieties and within 'short' varieties. The best short varieties took up 31-38 kg/ha more $\mathrm{N}$ than the worst, and grain-NutE was $24-42 \%$ better, depending on $\mathrm{N}$-rate. Up to $77 \%$ of the variation in grain-NutE was accounted for by yield. All interactions between the factors 'Variety', 'Year', and 'N-rate' were highly significant, but only 'Year $\times$ N-rate' made an important contribution to the variation. There was a near-functional inverse relationship between grain-NutE and grain $\% \mathrm{~N}$; high-quality wheat (high grain \%N) can be expected to have a low grain-NutE. The four key variables determining N-efficiency in a wheat crop - grain yield, grain \% $\mathrm{N}$, total N-uptake and nitrogen harvest index (NHI) - are ultimately constrained by the law of conservation of matter. Improving grain-NutE for fixed total-Nup and NHI can only be achieved at the expense of grain \%N. To improve grain-NutE and maintain grain \% requires a simultaneous increase in NHI and grain starch yield which may be difficult to achieve in practice. The law of conservation of matter ultimately sets a limit on the physiological and agronomic processes that determine crop $\mathrm{N}$ requirements. A high yield of high-quality grain (high grain $\% \mathrm{~N}$ ) requires a high input and uptake of nitrogen.
\end{abstract}

Crown Copyright @ 2010 Published by Elsevier B.V. All rights reserved.

\section{Definitions}

'Nitrogen efficiency' can have many meanings in the context of crop production and the literature contains a plethora of definitions (Good et al., 2004; Fageria et al., 2008). Basically, there are two primary efficiencies to consider, fertilizer efficiency and crop efficiency. Fertilizer efficiency is the fraction of freshly applied fertilizer-N that is recovered in the current crop. To measure this, the fertilizer must be labelled with ${ }^{15} \mathrm{~N}$ to differentiate fertilizer$\mathrm{N}$ from indigenous soil-N. Powlson et al. (1992) found that winter wheat grown in eastern England recovered 68\% on average of the applied ${ }^{15} \mathrm{NH}_{4}{ }^{15} \mathrm{NO}_{3}, 18 \%$ was retained in the topsoil (as nitrate

\footnotetext{
* Corresponding author. Tel.: +44 (0)1582 763 133; fax: +44 (0)1582 760981

E-mail address: peter.barraclough@bbsrc.ac.uk (P.B. Barraclough).
}

and ammonium ions in the soil solution, as exchangeable ammonium ions on clays, and as organic-N incorporated into microbes), and $14 \%$ was lost by leaching and de-nitrification. A less accurate, but more easily measured, fertilizer efficiency is the 'apparent fertilizer recovery efficiency' which is the total N-uptake (in the above-ground parts of the crop at maturity) at a given fertilizer$\mathrm{N}$-rate less uptake at zero $\mathrm{N}$-rate, divided by the $\mathrm{N}$-applied. This is an 'apparent' recovery because part of the total uptake will be from mineralized soil organic- $\mathrm{N}$ and the amount mineralized varies with the amount of fertilizer that has been applied. A third, and more general, measure of fertilizer efficiency is the $\mathrm{N}$ removed in grain divided by the $\mathrm{N}$-applied as fertilizer. On a global basis, just $33 \%$ of the fertilizer- $\mathrm{N}$ applied to cereals is removed in harvested grain (Raun and Johnson, 1999).

Crop N-efficiency can be defined in terms of the stability of grain yield at high- and low-N supply (Le Gouis and Pluchard, 1996). Vari- 
eties with this attribute would obviously be of great value where fertilizer was expensive or responses to $\mathrm{N}$ were limited by chronically poor growing conditions such as drought. The weakness of this criterion is that a variety with intrinsically low yield potential at both high-N and low-N supply, but with great stability, would out-rank a variety with intrinsically high-yield potential at high-N supply, but much reduced yield at low-N supply. In intensive systems when grain/fertilizer price ratios are favourable, farmers will always choose the latter variety.

Crop N-efficiency can be partitioned into the capture of $\mathrm{N}$ by roots (uptake efficiency) and its conversion to grain by shoots (utilization efficiency) (Moll et al., 1982). Total nitrogen uptake efficiency (total-NupE) is defined as all the $\mathrm{N}$ in the above-ground parts of the crop at maturity (total-Nup) divided by all the N supplied by fertilizer and soil during the growing season. Total nitrogen utilization efficiency (total-NutE) is the total dry matter yield (grain plus straw) divided by all the $\mathrm{N}$ in the above-ground parts of the crop at maturity. Grain nitrogen utilization efficiency (grain-NutE) is the grain dry matter yield divided by all the $\mathrm{N}$ in the above-ground parts of the crop at maturity. The product total-NupE $\times$ grain-NutE $=$ NUE, the overall crop N-use efficiency, which is grain dry matter yield divided by total N supply. Novoa and Loomis (1981) had earlier termed NUE the agronomic efficiency, NupE the recovery efficiency, and NutE the physiological efficiency. The subjects of this paper are total N-uptake (total-Nup) and grain N-utilization efficiency (grainNutE).

\section{Introduction}

Nitrogen is a primary driver of crop production. Given ample sunlight and water and favourable temperatures, yields of dry matter and grain are closely linked to the availability and uptake of nitrogen. The introduction of N-responsive, short-straw wheat varieties in the 1970s (semi-dwarfs) saw a doubling of $\mathrm{N}$-fertilizer use and grain yield in the UK (Austin, 1999). The new varieties and favourable production economics encouraged excessive use of fertilizers with consequences for the environment which have become all too apparent. Currently, the challenge is to maintain or improve productivity and profits with reduced inputs; basically to farm more cleanly and efficiently. Wheat breeders in the UK have consistently targeted improved grain yield under high inputs of fertilizer and crop protection chemicals, but nitrogen efficiency per se has never been a target. In a review of the water and nitrogen efficiency of wheat nearly 30 years ago, Fischer (1981) concluded that whilst there was scope to breed for nitrogen uptake efficiency, there was no need to breed independently for nitrogen utilization efficiency as this automatically came with improved yield.

Progress in breeding for yield potential is well documented in the literature (see for example Austin et al., 1980; Cox et al., 1988; Slafer and Andrade, 1991; Brancourt-Hulmel et al., 2003). It is generally accepted that the greater yield potential of short-straw compared with long-straw varieties has been achieved by partitioning more dry matter to grain at the expense of straw (a higher grain harvest index (GHI)) and not by greater total dry matter production, more $\mathrm{N}$-uptake, or better photosynthesis. Moreover, this yield potential can be fully realised at high N-rates as short-straw varieties are less prone to lodging. Short-straw varieties have more grains per ear giving greater yield for the same total $\mathrm{N}$-uptake and total dry matter production. By definition this means greater grainNutE (Fischer and Wall, 1976). There is evidence that increased dry matter production has contributed to recent gains in yield potential of short-straw varieties (Shearman et al., 2005; Foulkes et al., 2007).

There is an extensive global literature on NupE and NutE in wheat. The small selection of papers cited here illustrates the points of agreement and conflict evident in the literature. The papers report on multi-factorial, multi-year field trials on winter wheat
(Triticum aestivum), and cover the key issues in nitrogen efficiency differences between 'tall' (old) and 'short' (new) varieties, variation within 'short' varieties, the relative importance of NupE and NutE to NUE, gene $\times$ environment $(\mathrm{G} \times \mathrm{E})$ interactions, and relationships between $\mathrm{N}$-efficiency and yield and quality.

Van Sanford and MacKown (1986) studied 25 varieties at a single $\mathrm{N}$-rate over 2 years in Kentucky, USA. They found significant variation in NUE with total-NupE accounting for 54\% of the variation. There were no significant $\mathrm{G} \times \mathrm{E}$ interactions for NUE. Dhugga and Waines (1989) studied 12 varieties ( 3 tall) at $3 \mathrm{~N}$-rates over 2 years in California, USA. There was genotypic variation in total-NupE and grain-NutE with total-NupE being the dominant component of NUE (62-70\%) at all N-rates. Ortiz-Monasterio et al. (1997) studied 10 varieties ( 2 tall) at $4 \mathrm{~N}$-rates over 3 years in Mexico. NUE was found to track yield. There was genetic variation in total-Nup and grainNutE between tall and short varieties and within short varieties. Total-NupE contributed more to variation in NUE at low N, with equal contributions from NupE and NutE at medium N, and grainNutE contributed more at high $\mathrm{N}$, the opposite of what Dhugga and Waines had found. There was a significant variety $\times \mathrm{N}$ interaction for grain-NutE, but not for total-Nup. Le Gouis et al. (2000) studied 20 varieties ( 2 tall) at $2 \mathrm{~N}$-rates over 2 years in France. They found genetic variation in total-NupE and total-NutE. The contribution of total-NupE to the variation in NUE was $64 \%$ at low-N and $30 \%$ at high-N (in agreement with Ortiz-Monasterio et al.). There was significant $\mathrm{G} \times \mathrm{N}$ interaction for total-NupE but not for total-NutE.

The literature on N-efficiency in UK varieties is sparse. Austin et al. (1977) reported large differences in total-Nup for 43 genotypes of T. aestivum which were largely due to differences in growth rather than $\mathrm{N}$ concentration. Countless trials have been conducted in the UK for selecting new wheat varieties with the main criterion being yield under high inputs (HGCA, 2009). Unfortunately, no measurements of straw yield and straw \%N, which are needed to calculate NupE and NutE, were made in these trials. Foulkes et al. (2006) used this data to estimate total-NupE and grain-NutE for 178 varieties by assuming fixed standard values for grain harvest index and nitrogen harvest index (NHI). On the basis of these assumptions, they found significant genetic variation in both total-NupE and grain-NutE.

The aim of the present study was to quantify the genotypic variation in total N-uptake (total-Nup) and grain N-utilization efficiency (grain-NutE) in a selection of elite wheat varieties (T. aestivum) differing in yield potential and grain quality. Yield and quality (grain $\% \mathrm{~N}$ ) of wheat are inversely related when varieties or environments are compared (Kramer, 1979; Oury et al., 2003), and it may not be possible to have a high-yielding, high-quality, N-efficient wheat. A second aim was to show how five key components of crop Nefficiency - grain yield, grain \% $\mathrm{N}$, nitrogen harvest index, total $\mathrm{N}$-uptake, and grain-NutE - are related and ultimately constrained by the law of conservation of matter (1st Law of Thermodynamics).

\section{Materials and methods}

\subsection{Site}

Rothamsted is in southern England (latitude $52^{\circ} \mathrm{N}$, longitude $1^{\circ} \mathrm{W}$ ). The soil is a well-drained, flinty silt clay loam ( $25 \%$ clay) overlying clay with flints (50\% clay). This soil is designated as 'Batcombe Series' in the UK Soil Classification, 'Aquic Paleudalf' in the USDA system and 'Chromic Luvisol' in the FAO system (Avery and Catt, 1995).

\subsection{Rainfall}

Annual rainfall at Rothamsted is typically $700 \mathrm{~mm}$ which is spread evenly over the year. Spring and summer rainfall for the 
Table 1

Monthly rainfall in spring and summer ( $\mathrm{mm}$ ) at Rothamsted in the years 2004-2007. Six-monthly totals and 30-year averages (Avg, 1971-2000) are shown.

\begin{tabular}{rlrrllrl}
\hline Year & March & April & May & June & July & August & Total \\
\hline 2004 & 47 & 82 & 52 & 32 & 50 & 113 & 376 \\
2005 & 43 & 66 & 44 & 40 & 43 & 59 & 295 \\
2006 & 50 & 51 & 89 & 15 & 36 & 110 & 351 \\
2007 & 58 & 3 & 136 & 72 & 87 & 64 & 420 \\
Avg & 54 & 54 & 50 & 60 & 42 & 54 & 314 \\
\hline
\end{tabular}

4 years of the experiments are given in Table 1 . In July, the mean maximum temperature is $21^{\circ} \mathrm{C}$ with $190 \mathrm{~h}$ of sunshine. Potential evapo-transpiration normally exceeds rainfall during the May-August period by $100 \mathrm{~mm}$, but the available soil water capacity of $135 \mathrm{~mm}$ means that drought-induced yield reductions are rare on this soil for deep rooting, winter-sown crops (Barraclough et al., 1989).

\subsection{Husbandry}

The trials were conducted in different fields at Rothamsted over four seasons - 2004 (Black Horse field), 2005 (Fosters field), 2006 (Meadow field) and 2007 (Black Horse field) (harvest years are shown). All crops were a first wheat following winter oats to avoid effects from the root disease 'take all' which is prevalent in continuous wheat crops in the UK. The winter oats were given modest amounts of $\mathrm{N}$-fertilizer which ensured relatively low residual soil$\mathrm{N}$-min levels for the following wheat. All crops were autumn-sown (including the spring varieties) predominantly in mid-October, but in a window spanning 2 October to 19 November. Seed was precision-drilled at a rate of 350 seeds $/ \mathrm{m}^{2}$ in $12.5 \mathrm{~cm}$ rows in plots measuring $3 \mathrm{~m}$ by $10-20 \mathrm{~m}$. Available soil P, K and Mg was Index 2 on all fields which is non-limiting to yield (MAFF, 2000). The crops were top-dressed with potassium sulphate in March supplying sulphur at a rate of $20 \mathrm{~kg}-\mathrm{S} / \mathrm{ha}$. Crops were given growth regulator and protected against weeds, pests and diseases as required.

\subsection{Nitrogen regimes}

Nitrogen fertilizer, as ammonium nitrate prills, was applied at five rates of $0,50,100,200$ and $350 \mathrm{~kg}-\mathrm{N} / \mathrm{ha}$, hereafter labelled as N0, N50, N100, N200 and N350, respectively. Only N0 and N200 were applied every year. The fertilizer was applied as a top-dressing in a 3-way split in March (nominally GS 24), April (GS 31) and May (GS 32) (Table 2).

\subsection{Varieties}

Over the 4 years, 39 wheat varieties ( $T$. aestivum L.) were grown in all, with a core of 14 being grown every year (Table 3 ). The varieties represented a relatively narrow subset of elite genetic material with all but three carrying dwarfing genes. There were 3

Table 2

Nitrogen fertilizer rates and splits (kg-N/ha).

\begin{tabular}{|c|c|c|c|c|}
\hline 2004 & 50 & & 200 & 350 \\
\hline 2005 & 0 & & 200 & \\
\hline 2006 & 0 & 100 & 200 & \\
\hline 2007 & 0 & 100 & 200 & 350 \\
\hline Total & March (GS 24) & April (GS 31) & & May (GS 32) \\
\hline \multicolumn{5}{|l|}{0} \\
\hline 50 & 50 & & & \\
\hline 100 & 50 & 50 & & \\
\hline 200 & 50 & 100 & & 50 \\
\hline 350 & 50 & 250 & & 50 \\
\hline
\end{tabular}

Table 3

Wheat varieties grown in 2004-2007 showing Code, Year of release (approx.), NABIM Group or Country (F - France, G - Germany, P - Poland), and Years in the trials.

\begin{tabular}{|c|c|c|c|c|}
\hline Variety & Code & Listed & Nabim & Years \\
\hline Avalon & AV & 1979 & 1 & 3 \\
\hline Hereward & $\mathrm{HE}$ & 1991 & 1 & 4 \\
\hline Hurley & $\mathrm{HU}$ & 2003 & 1 & 4 \\
\hline Malacca & MA & 1999 & 1 & 4 \\
\hline Mercia & ME & 1986 & 1 & 3 \\
\hline Maris Widgeon (tall) & MW & 1964 & 1 & 4 \\
\hline Shamrock & $\mathrm{SH}$ & 1999 & 1 & 3 \\
\hline Solstice & SL & 2002 & 1 & 4 \\
\hline Spark & SP & 1993 & 1 & 1 \\
\hline Xi19 & XI & 2002 & 1 & 4 \\
\hline Cadenza & $\mathrm{CA}$ & 1991 & 2 & 4 \\
\hline Cordiale & $\mathrm{CO}$ & 2004 & 2 & 2 \\
\hline Einstein & EI & 2003 & 2 & 1 \\
\hline Lynx & LY & 1993 & 2 & 4 \\
\hline Rialto & $\mathrm{RL}$ & 1992 & 2 & 1 \\
\hline Scorpion & SC & 2001 & 2 & 1 \\
\hline Soissons & SS & 1995 & 2 & 4 \\
\hline Beaver & $\mathrm{BE}$ & 1990 & 3 & 3 \\
\hline Claire & $\mathrm{CL}$ & 1999 & 3 & 3 \\
\hline Riband & RI & 1989 & 3 & 4 \\
\hline Robigus & RO & 2003 & 3 & 3 \\
\hline Istabraq & IS & 2004 & 4 & 3 \\
\hline Napier & NA & 2000 & 4 & 2 \\
\hline Savannah & SA & 1998 & 4 & 3 \\
\hline Paragon (spring) & $\mathrm{PA}$ & 1999 & 1 & 4 \\
\hline Chablis (spring) & $\mathrm{CH}$ & 1995 & 2 & 1 \\
\hline Arche & AR & & $\mathrm{F}$ & 1 \\
\hline Batis & BA & & G & 4 \\
\hline Caphorn & $\mathrm{CP}$ & & $\mathrm{F}$ & 1 \\
\hline Cappelle Desprez (tall) & $\mathrm{CD}$ & 1953 & $\mathrm{~F}$ & 1 \\
\hline Enorm & EN & & G & 1 \\
\hline Flanders (tall) & FL & & $\mathrm{F}$ & 1 \\
\hline Isengrain & IG & & $\mathrm{F}$ & 1 \\
\hline Monopol & MO & & G & 4 \\
\hline Opus & OP & & G & 1 \\
\hline PBis & PB & & G & 1 \\
\hline Petrus & $\mathrm{PE}$ & & G & 1 \\
\hline Sokrates & SK & & G & 4 \\
\hline Zyta & ZY & & $\mathrm{P}$ & 1 \\
\hline
\end{tabular}

old, tall varieties (Cappelle Desprez, Flanders and Maris Widgeon), 2 spring varieties (Paragon and Chablis), 11 continental varieties mainly from Germany and France, and 23 short-straw varieties which appeared on the UK recommended list between 1979 and 2004. The UK varieties spanned the quality spectrum from 'bread' to 'feed' wheat as classified by the National Association of British and Irish Millers (NABIM, 2009). NABIM Group 1 comprises hard wheat with consistently good bread-making properties, Group 2 has bread-making potential, Group 3 includes soft varieties suitable for making biscuits and cakes, and wheat in Group 4 is generally only suitable for animal feed.

\subsection{Experimental design and statistical analysis}

In 2004, 32 varieties were grown at $4 \mathrm{~N}$-rates. The varieties were fully randomised in 3 blocks whilst the N-rates were arranged in 4 sub-blocks in each main block (384 plots). In 2005-06-07, the treatments were arranged in three fully randomised blocks. In 2005, there were 20 varieties at $2 \mathrm{~N}$-rates ( 120 plots). In 2006 , there were 24 varieties at $3 \mathrm{~N}$-rates ( 216 plots). In 2007, there were 24 varieties at $4 \mathrm{~N}$-rates (288 plots). Results for the 4 years were analysed by ANOVA using a Residual Maximum Likelihood Programme (REML) to cope with the different design and treatment combinations each 
Table 4

Soil mineral-N $\left(\mathrm{NO}_{3}-\mathrm{N}\right.$ plus $\left.\mathrm{NH}_{4}-\mathrm{N}\right)$ to $90 \mathrm{~cm}$ depth in February in 2004-2007 (kg$\mathrm{N} / \mathrm{ha}$ ).

\begin{tabular}{llllll}
\hline Year & Cores/block & Block 1 & Block 2 & Block 3 & Mean \\
\hline 2004 & 4 & 57 & 96 & 68 & 74 \\
2005 & 6 & 13 & 25 & 53 & 30 \\
2006 & 12 & 90 & 87 & 82 & 86 \\
2007 & 16 & 50 & 57 & 50 & 52 \\
\hline
\end{tabular}

year. Least significant differences (LSD) are reported at the 5\% level of confidence (probably significant) $\left({ }^{*} P<0.05\right)$.

\subsection{Soil N-min measurements}

Soil cores were taken to $90 \mathrm{~cm}$ depth in February, before fertilizer was applied, for the analysis of mineral- $\mathrm{N}\left(\mathrm{NO}_{3}-\mathrm{N}\right.$ and $\left.\mathrm{NH}_{4}-\mathrm{N}\right)$. The cores were taken with a 'Hydro Soil Sampler' fitted with a $3 \mathrm{~cm}$ diameter semi-cylindrical auger. Duplicate cores were taken from random positions across each field. In total, 12 cores were taken in 2004 and 18, 36 and 48 cores in 2005, 2006 and 2007, respectively. The cores were split into three depth sections, $0-30$, $30-60$ and $60-90 \mathrm{~cm}$ and the mineral-N extracted by shaking $40 \mathrm{~g}$ of fresh soil with $100 \mathrm{ml}$ of $2 \mathrm{M} \mathrm{KCl}$ for $2 \mathrm{~h}$. The slurry was allowed to settle for $30 \mathrm{~min}$ and then filtered (Whatman No.1). The solution was analysed for nitrate-N and ammonium-N with a 'Skalar San Plus Analyser'. Concentrations in units of ppm in the extracted solution were converted to field units of $\mathrm{kg}-\mathrm{N} / \mathrm{ha}$ by assuming a standard value of $1.5 \mathrm{~g} / \mathrm{cm}^{3}$ for soil bulk density (Avery and Bullock, 1969).

Soil mineral-N (N-min) in individual cores, i.e. at specific locations in a field, was very variable ranging from 11 to $145 \mathrm{~kg}-\mathrm{N} / \mathrm{ha}$ across sites and seasons. Average whole field values for each year ranged from 30 to $86 \mathrm{~kg}-\mathrm{N} /$ ha giving an overall average of $60 \mathrm{~kg}$ $\mathrm{N} /$ ha (Table 4).

\subsection{Crop measurements}

Crops were combine-harvested at grain maturity in the period 8th-31st August. A $20 \mathrm{~m}^{2}$ combine cut $(2 \times 10 \mathrm{~m})$ was taken from the centre of each plot and the grain and straw weighed fresh. Dry matter yields of grain and straw (including chaff) were determined by oven-drying $\mathrm{ca}$. $100 \mathrm{~g}$ sub-samples of the fresh material overnight at $105^{\circ} \mathrm{C}$. Straw yields were determined by different methods in different years. In 2004, 2006 and 2007, straw was cut by the combine harvester. In 2004 and 2006, combine straw yields were adjusted for the residual field stubble by hand-cutting $1 \mathrm{~m}^{2}$ quadrats of stubble at ground level on all plots in one Block. Average values of stubble were calculated for each $\mathrm{N}$-rate and applied to all plots for these years. In 2007, no stubble adjustments were made. In 2005 , combine grain yield was determined but not combine straw yield. In that year, a final hand-harvest was made by cutting a $1 \mathrm{~m}^{2}$ quadrat at ground level from each plot. Total-N in grain and straw dry matter was determined on oven-dried $\left(80^{\circ} \mathrm{C}\right.$ overnight $)$ milled samples by the Dumas combustion method (Dumas, 1831) using a 'Leco N-analyser'.

Grain and straw yields and \%N in DM from the combine samples were used for subsequent calculations in all years with the exception of 2005. In that year, combine grain yield and grain $\% \mathrm{~N}$ values were used, but all derived parameters were calculated from the hand-harvest measurements. The derived parameters of total $\mathrm{N}$ uptake, grain-NutE, GHI and NHI were calculated from these basic combine and hand measurements. Total N-uptake (total-Nup) was calculated and not total-NupE because soil-N-min had not been measured on every plot.

\section{Results}

\subsection{Variety rankings}

Several varieties were grown for just 1 year (2004) including most of the continental varieties (except Batis, Monopol and Sokrates) plus Einstein, Flanders, Rialto, Scorpion, and Spark of the UK varieties, and the spring variety Chablis (Table 3 ). All varieties were included in the statistical analysis, but consistent performance over several years was deemed more important than a single-season result, so extreme rankings (high or low) were only given prominence if varieties were grown for 2 or more years.

The effects of the three factors variety $(V)$, N-rate $(N)$ and year $(Y)$ on the six crop variables grain yield, grain $\% \mathrm{~N}$, total $\mathrm{N}$-uptake, grainNutE, grain harvest index and nitrogen harvest index are shown in Fig. 1. The contribution of the three factors, and their interactions, to the overall variation can be assessed by comparing values of the ratio 'Wald statistic/degrees of freedom' (W/df). All the W/df ratios given below were 'highly significant' $\left({ }^{* * *} P<0.001\right)$.

\subsubsection{Grain yield}

Grain yield ranged from 2.07 to $11.84 \mathrm{t} /$ ha $(85 \% \mathrm{DM})$ depending on the treatment (Fig. 1a). N-rate had the greatest effect on yield with a W/df ratio of 4923 , the 2 -way interaction $Y \times N$ was next (W/df 61 ), followed by variety (W/df 42 ), and year (W/df 16). All other interactions including the 3-way interaction, $Y \times N \times V$, were highly significant but made only small contributions to the variation. Yields were most variable in the zero fertilizer treatment (NO). Under these conditions the residual soil-N-min was sufficient for an average yield of $4.10 \mathrm{t} / \mathrm{ha}$. Yields at the five $\mathrm{N}$-rates averaged over variety and year were $4.10,4.68,8.62,9.27$ and 9.49 t/ha $(85 \% \mathrm{DM})$ at N0, N50, N100, N200 and N350, respectively. There were significant varietal differences in yield at all N-rates. Generally, the UK feed varieties had the highest ranking yields at all N-rates, whilst the UK bread varieties were lower quartile performers (Table 5). The old tall variety, Maris Widgeon, consistently had the lowest yields. There was heavy rainfall in August 2004 which caused Maris Widgeon and Cappelle Desprez to lodge at the highest N-rate.

\subsubsection{Grain $\% N$}

Grain \%N ranged from $1.08 \%$ to $2.79 \%$ (in DM) depending on Nrate (W/df 3840), year (W/df 127), $Y \times N(\mathrm{~W} / \mathrm{df} 51)$ and variety $(\mathrm{W} / \mathrm{df}$ 44) (Fig. 1b). Average grain \%N was unaffected by N-rates up to N100 (1.44-1.51\%), but increased to $2.03 \%$ at N200 and to $2.40 \%$ at N350. The standard quality requirement for milling wheat in the UK is $13 \%$ protein in DM equivalent to $2.3 \% \mathrm{~N}$ in DM based on a conversion factor of 5.7 (Lopez-Bellido et al., 2004). Very few varieties attained this standard even at N200, but most varieties, with the exception of the high-yielding feed varieties, attained the standard at N350. There were significant varietal differences in grain $\% \mathrm{~N}$ at all $\mathrm{N}$-rates. The poorer yielding tall varieties and some continental varieties consistently had the best grain \% $\mathrm{N}$ rankings, whilst high-yielding feed varieties consistently ranked low (Table 5).

\subsubsection{Total $N$-uptake}

Total N-uptake ranged from 31 to $264 \mathrm{~kg}-\mathrm{N} /$ ha depending on $\mathrm{N}-$ rate $(\mathrm{W} / \mathrm{df} 7649), Y \times N(\mathrm{~W} / \mathrm{df} 22)$, variety $(\mathrm{W} / \mathrm{df} 6)$, and year $(\mathrm{W} / \mathrm{df}$ 5) (Fig. 1c). Average N-uptakes were 57, 72, 124, 186 and $229 \mathrm{~kg}$ N/ha at N0, N50, N100, N200 and N350, respectively. There was sufficient soil-N-min for an average uptake of $57 \mathrm{~kg}-\mathrm{N} / \mathrm{ha}$ where no fertilizer was applied. The mean residual soil-N-min in February to $90 \mathrm{~cm}$ depth was $60 \mathrm{~kg}-\mathrm{N} / \mathrm{ha}$ giving a mean apparent uptake efficiency of $95 \%$ for soil-N-min. A group of varieties consisting of Zyta (Polish, 1-year), Chablis (spring, 1-year), Cappelle Desprez (tall, 1-year) and Maris Widgeon (tall) had abnormally low uptakes at N200 and/or N350, matching the generally low grain yields of 
(1a) Grain Yield (LSD 1.17)

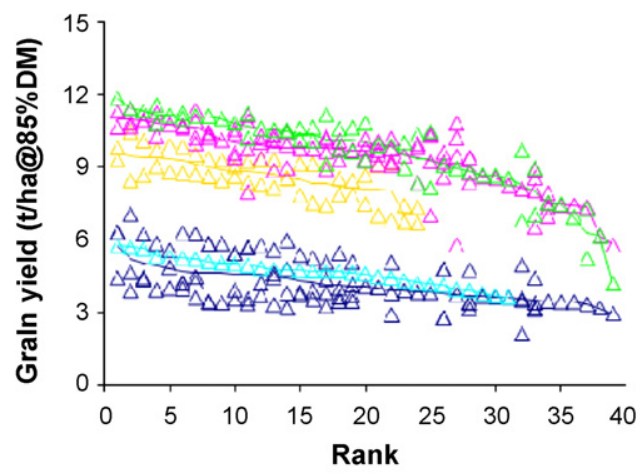

(1b) Grain \%N (LSD 0.17)

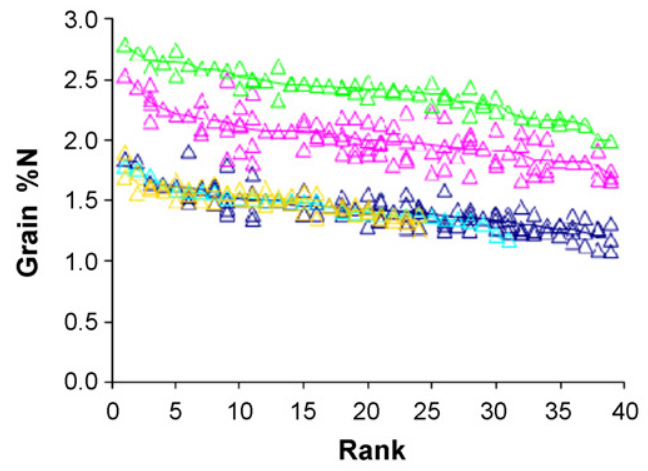

(1c) Total N-uptake (LSD 24)

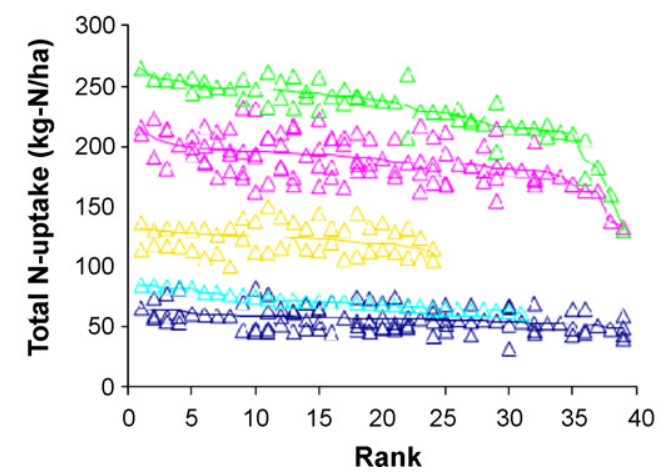

(1d) Grain-NutE (LSD 5.4)

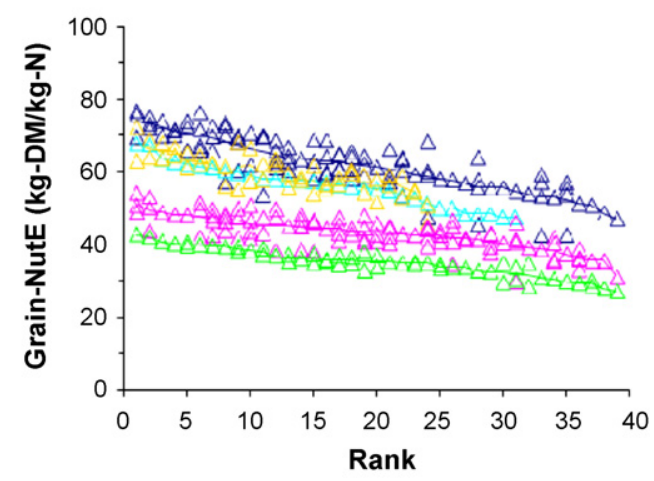

(1e) Grain Harvest Index (LSD 4.8)

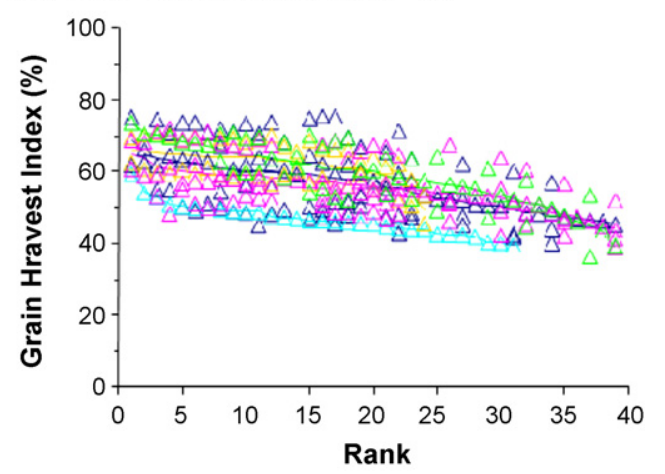

(1f) Nitrogen Harvest Index (LSD 4.1)

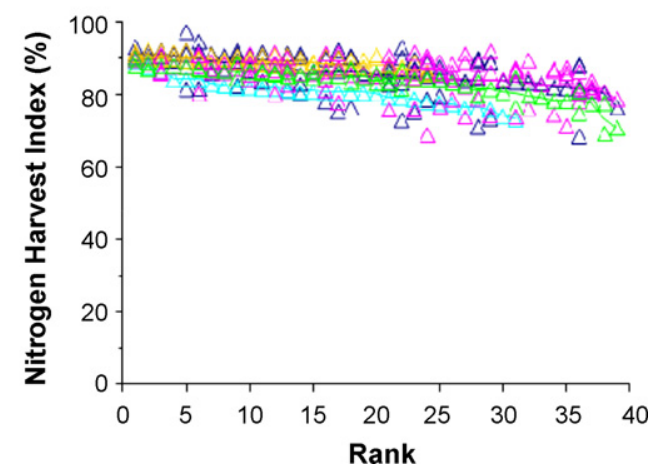

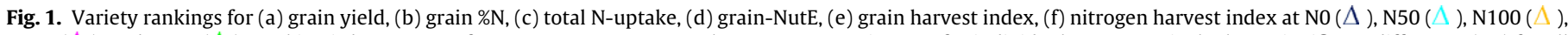

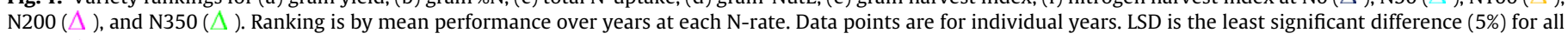
comparisons.

these varieties at these $\mathrm{N}$-rates. Variation in $\mathrm{N}$-uptake was large with an overall LSD (5\%) of $24 \mathrm{~kg}-\mathrm{N} / \mathrm{ha}$. Accordingly, varietal differences in uptake were only statistically significant at N200 and N350. The varietal range in total $\mathrm{N}$-uptake excluding varieties grown for 1 year and older, tall varieties was 31 (182-213) and 38(213-251) kg$\mathrm{N} /$ ha at N200 and N350, respectively. Most of the variation in uptake was due to differences in growth (total dry matter production) rather than to differences in N-concentration (total \% N) (not shown). The highest ranking varieties were not confined to any particular quality group (Table 5). The varietal range of apparent fertilizer recoveries at N200 was 63-78\%.

\subsubsection{Grain-NutE}

Grain-NutE ranged from 27 to $77 \mathrm{~kg}-\mathrm{DM} / \mathrm{kg}-\mathrm{N}$ depending on $\mathrm{N}$-rate (W/df 2986), year (W/df 122), $Y \times N(\mathrm{~W} / \mathrm{df} 88$ ), and variety (W/df 43) (Fig. 1d). Average grain-NutE values were 61, 56, 60, 43 and $35 \mathrm{~kg}-\mathrm{DM} / \mathrm{kg}-\mathrm{N}$ at N0, N50, N100, N200 and N350, respec- tively. There were significant varietal differences in grain-NutE at all N-rates. Excluding the tall variety, Maris Widgeon, which had the lowest ranking at all N-rates, and varieties grown for 1 year, the varietal ranges in grain-NutE were 74-53, 68-48, 68-55, 51-39 and $40-32 \mathrm{~kg}-\mathrm{DM} / \mathrm{kg}-\mathrm{N}$ at N0, N50, N100, N200 and N350, respectively. So the best short-straw varieties out-performed the worst by $24-42 \%$, depending on N-rate. In general, rankings matched those of yield with respect to quality groups (Table 5). So, the UK feed varieties as exemplified by Istabraq and Savannah, tended to have the highest rankings and the UK bread varieties and continental varieties tended to be lower quartile performers.

\subsubsection{Grain harvest index}

Grain harvest index ranged from $37 \%$ to $76 \%$ depending on year (W/df 1101), N-rate (W/df 59), variety (W/df 58), and $Y \times N(\mathrm{~W} / \mathrm{df}$ 44) (Fig. 1e). Average GHI values were $51 \%, 48 \%, 58 \%$ and $67 \%$ in 2004, 2005, 2006 and 2007, respectively. Much of the variability 
between years was connected to the different methods used to measure straw yields and whether adjustments had been made for stubble left by the combine harvester. In 2007, no adjustments for stubble were made which resulted in the greatest values of GHI. In 2005 , the straw was cut by hand which resulted in the smallest, and probably the most accurate, values of GHI. On the basis of physical considerations, Austin et al. (1980) doubted the viability of varieties having GHI values much above $60 \%$. There was no obvious trend in $\mathrm{GHI}$ with $\mathrm{N}$-rate. Average $\mathrm{GHI}$ values were $56 \%, 47 \%$, $62 \%, 55 \%$ and $59 \%$ at N0, N50, N100, N200 and N350, respectively. There were significant varietal differences in GHI, but there was no consistent pattern with respect to quality group.

\subsubsection{Nitrogen harvest index}

Nitrogen harvest index ranged from $69 \%$ to $98 \%$ depending on year (W/df 210), N-rate (W/df 117), $Y \times N$ (W/df 28), and variety (W/df 17) (Fig. 1f). Average NHI values for the 4 years were $83 \%$, $80 \%, 88 \%$ and $89 \%$ in 2004, 2005, 2006 and 2007, respectively. Some of the variability in NHI between years, like GHI, was due to the different methods used to measure straw. The hand-cut method used in 2005 gave the lowest NHI values. There was no obvious trend in NHI with $\mathrm{N}$-rate, in fact of all the crop variables, $\mathrm{NHI}$ was the least affected by $\mathrm{N}$-rate. Average NHI values were $86 \%, 81 \%, 89 \%$, $85 \%$ and $84 \%$ at N0, N50, N100, N200 and N350, respectively. There were significant varietal differences in $\mathrm{NHI}$ at all $\mathrm{N}$-rates, but no consistent pattern with respect to quality group.

\subsubsection{Summary of rankings at $N 200$}

The performance rankings of all the varieties at N200 in relation to grain end-use (NABIM quality groups) are summarised in Table 5. NABIM Group 3 varieties ('biscuit') and NABIM Group 4 varieties ('feed'), had the best all-round rankings with respect to grain yield, $\mathrm{N}$-uptake and $\mathrm{N}$-utilization, but were some of the poorest performers with respect to grain-N. The best grain-N performers were NABIM Group 1 bread wheat and the continental varieties.

\subsection{Interactions}

On the basis of the REML analysis, all interactions between the three factors, 'Variety' $(V)$, 'N-rate' $(N)$ and 'Year' $(Y)$ were highly significant $\left({ }^{* * *} P<0.001\right)$ for each of the variables, but with the exception of $Y \times N$ they made only small contributions to the variation in each variable.

A more specific approach to interactions is to compare rankings under different treatments or environments. When a variety performs consistently over years or $\mathrm{N}$-rates for example, then genetic control is over-riding the external factors. If ranking differs between years or $\mathrm{N}$-rates, this indicates the presence of gene $\times$ environment

(2a) Mean Total N-uptake Rankings

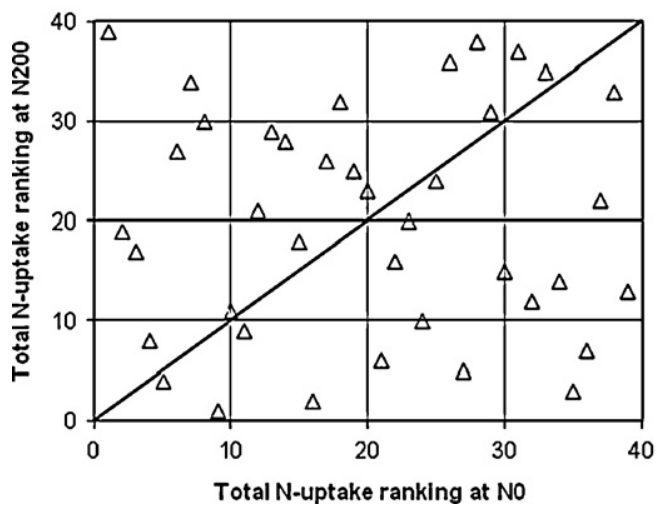

$(\mathrm{G} \times \mathrm{E})$ or gene $\times$ nitrogen $(\mathrm{G} \times \mathrm{N})$ interactions. Examples of how variety performance was affected by $\mathrm{N}$-rate are given in Fig. 2 . There was no correlation between rankings at N200 and NO for total Nuptake (Fig. 2a) indicating a strong $\mathrm{G} \times \mathrm{N}$ interaction. A few varieties were close to the $1: 1$ line, some varieties were consistently good or bad at high or low $\mathrm{N}$, but most varieties performed inconsistently.

There was a reasonable correlation between grain-NutE rankings at N200 and N0 (Fig. 2b), indicating a weak $\mathrm{G} \times \mathrm{N}$ interaction with performance at high-N frequently matched by performance at low-N. For example, Savannah performed well at both high and low N, whilst the old, tall Maris Widgeon performed poorly at both $\mathrm{N}$ levels.

\subsection{Relationships}

Key relationships between the $\mathrm{N}$-related variables are shown in Fig. 3. Yield was positively correlated with total $\mathrm{N}$-uptake at each $\mathrm{N}$ rate with a curvilinear, diminishing-returns relationship emerging over all N-rates (Fig. 3a). There was significant scatter at each $\mathrm{N}$ rate indicating the influence of seasonal yield-determining factors. For example, a yield of $9 \mathrm{t} /$ ha was associated with uptakes ranging from 100 to $250 \mathrm{~kg}-\mathrm{N} / \mathrm{ha}$. There were similar relationships between total dry matter yield and total N-uptake (not shown). Grain \%N was poorly correlated with total $\mathrm{N}$-uptake at each $\mathrm{N}$-rate, but was positively correlated over all N-rates (Fig. 3b). Grain yield was negatively correlated with grain $\% \mathrm{~N}$ at each $\mathrm{N}$-rate (Fig. 3c). At rates up to $\mathrm{N} 100$, yield increased at the expense of $\% \mathrm{~N}$, but thereafter grain $\% \mathrm{~N}$ increased as yield reached a plateau.

Grain-NutE was positively correlated with yield at each N-rate (Fig. 3d). Much of the scatter was due to variation between years. When averages over years were plotted (Fig. 4), up to $77 \%$ of the genetic variation in grain-NutE was accounted for by yield depending on $\mathrm{N}$-rate. Examples of $\mathrm{N}$-efficiency greater than expected from yield, i.e. outliers above the trend-lines, were Claire (NO), Riband and Beaver (N50), Riband and Robigus (N100), Istabraq (N200), and Savannah (N350). Grain-NutE was not correlated with total-Nup at individual N-rates (Fig. 3e). In contrast, there was a near-functional inverse relationship between grain-NutE and grain \%N ( $\left.Y=140.03 \exp ^{-0.583 X} ; R^{2}=0.96\right)$ (Fig. 3f). High-quality bread wheat (high grain $\% \mathrm{~N}$ ) can be expected to have a low grain-NutE. Lemaire and Gastal (2009) found a similarly close relationship across different crop species, cereals, legumes and oilseeds.

\section{Discussion}

There are two ways to improve N-efficiency in wheat crops, better fertilizer management or better crop varieties. Fertilizer effi-

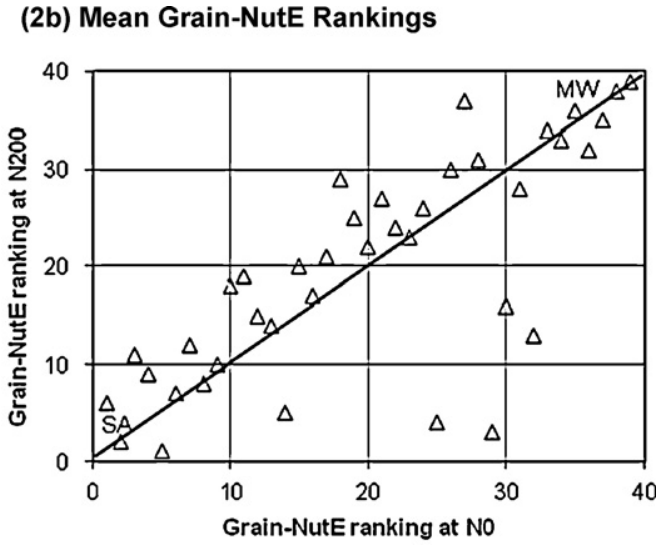

Fig. 2. Rankings at N200 vs. NO for (a) total N-uptake and (b) grain-NutE. Data points are means over years. SA is Savannah and MW is Maris Widgeon. 
Table 5

Variety performance at $200 \mathrm{~kg}-\mathrm{N} / \mathrm{ha}$ (N200) for grain yield, grain \%N, total N-uptake and grainNutE. Nabim quality group or country (F - France, G - Germany, P - Poland) are shown. 'UpperQ' ranked in the upper quartile; 'Inter-Q' ranked in the inter quartiles; 'Lower Q' ranked in the lower quartile.

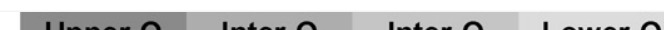

\begin{tabular}{|c|c|c|c|c|c|}
\hline Variety & Nabim & Yield & Grain \%N & $\begin{array}{c}\text { Total- } \\
\text { Nup }\end{array}$ & $\begin{array}{c}\text { Grain- } \\
\text { NutE }\end{array}$ \\
\hline Avalon & 1 & & & & \\
\hline Hereward & 1 & & & & \\
\hline Hurley & 1 & & & & \\
\hline Malacca & 1 & & & & \\
\hline Mercia & 1 & & & & \\
\hline Maris W & 1 & & & & \\
\hline Shamrock & 1 & & & & \\
\hline Solstice & 1 & & & & \\
\hline Spark & 1 & & & & \\
\hline Xi 19 & 1 & & & & \\
\hline Cadenza & 2 & & & & \\
\hline Cordiale & 2 & & & & \\
\hline Einstein & 2 & & & & \\
\hline Lynx & 2 & & & & \\
\hline Rialto & 2 & & & & \\
\hline Scorpion & 2 & & & & \\
\hline Soissons & 2 & & & & \\
\hline Beaver & 3 & & & & \\
\hline Claire & 3 & & & & \\
\hline Riband & 3 & & & & \\
\hline Robigus & 3 & & & & \\
\hline Istabraq & 4 & & & & \\
\hline Napier & 4 & & & & \\
\hline Savannah & 4 & & & & \\
\hline Paragon & 1 & & & & \\
\hline Chablis & 2 & & & & \\
\hline Arche & $\mathrm{F}$ & & & & \\
\hline Batis & G & & & & \\
\hline Caphorn & $\mathrm{F}$ & & & & \\
\hline Cappelle & $\mathrm{F}$ & & & & \\
\hline Enorm & G & & & & \\
\hline Flanders & $\mathrm{F}$ & & & & \\
\hline Isengrain & $\mathrm{F}$ & & & & \\
\hline Monopol & $\mathrm{G}$ & & & & \\
\hline Opus & $\mathrm{G}$ & & & & \\
\hline PBis & G & & & & \\
\hline Petrus & $G$ & & & & \\
\hline Sokrates & G & & & & \\
\hline Zyta & $\mathrm{P}$ & & & & \\
\hline
\end{tabular}

ciency can be improved by matching applications to crop demand and the weather. The problem here is one of long-range weather forecasting. Weather has a major influence on crop growth and grain yield ( $\mathrm{N}$ demand), and on the availability of soil and fertilizer$\mathrm{N}$ ( $\mathrm{N}$ supply). The difficulty of predicting the weather more than a few days ahead in a maritime climate like the UK is a major barrier to making accurate fertilizer recommendations.

The second way to improve N-efficiency in wheat crops is to breed varieties able to recover more $\mathrm{N}$ from soils and fertilizers (better NupE) and use it to make more grain (better NutE). In a wide-ranging review, Hirel et al. (2007) discussed how this might be achieved using a combination of whole-plant physiology and genetic approaches. The present study has shown that significant genetic variation exists in total-Nup and grain-NutE in a selection of UK winter wheat varieties. The greatest differences were between older, taller varieties and newer, shorter varieties, but there was significant variation among the shorter varieties. The varieties tested in this study were all elite commercial cultivars of hexaploid bread wheat ( $T$. aestivum) which represented a relatively narrow subset of genetic material. Greater differences would likely be found if the genetic net were to be cast more widely.

Roots capture mineral-N from the topsoil from recently applied fertilizer and from mineralized organic matter. Roots have to compete with several loss processes to do this. In northern Europe, ammonium nitrate is the main $\mathrm{N}$-fertilizer, and nitrate is leached from soil whenever the water-holding capacity is exceeded (usually in winter). Nitrate is also de-nitrified in water-logged, anaerobic soils (Addiscott and Powlson, 1992). As well as these losses, crops must compete with microbes in the topsoil for mineral-N (Recous et al., 1988). It is well known that if nitrogen is applied in several 
(3a) Grain Yield vs. Total N-uptake

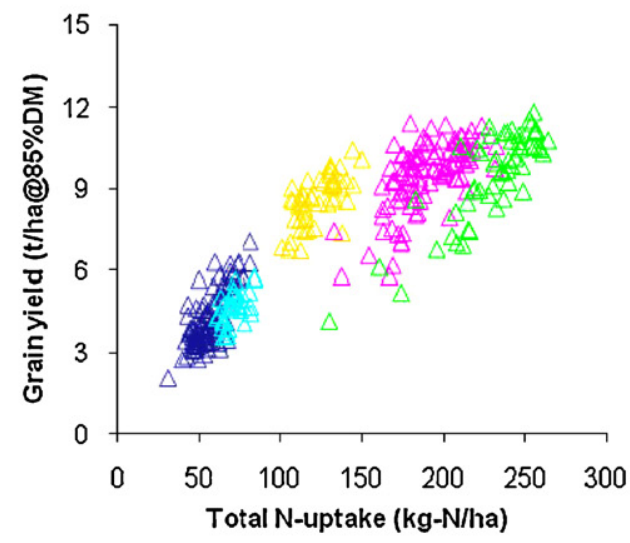

(3b) Grain $\% \mathrm{~N}$ vs. Total $\mathrm{N}$-uptake

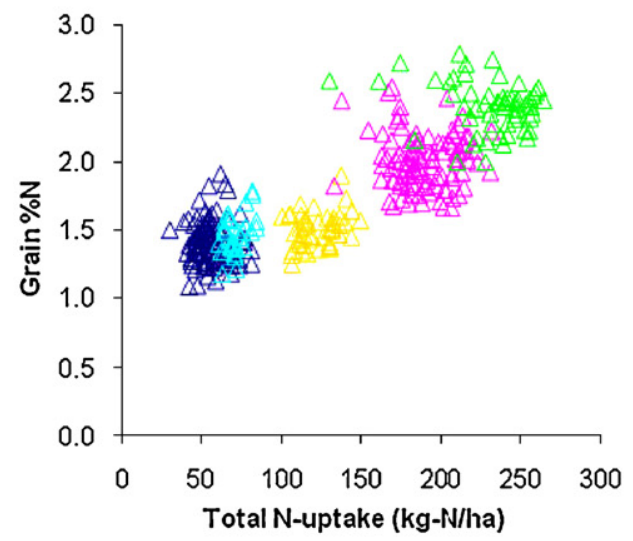

(3c) Grain Yield vs. Grain \% N

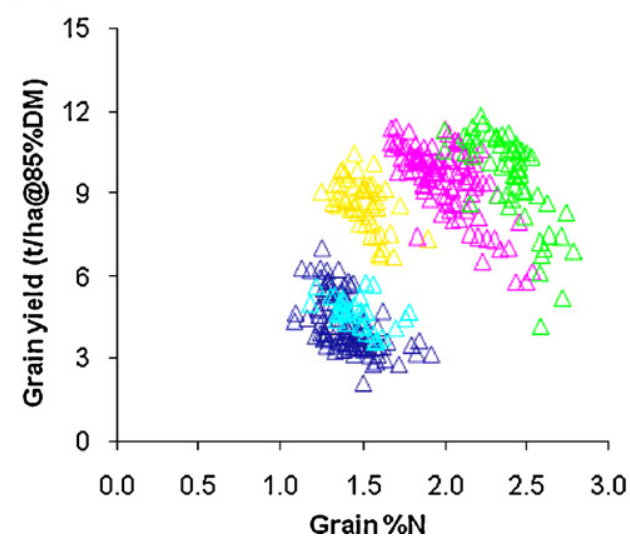

(3d) Grain-NutE vs. Grain Yield

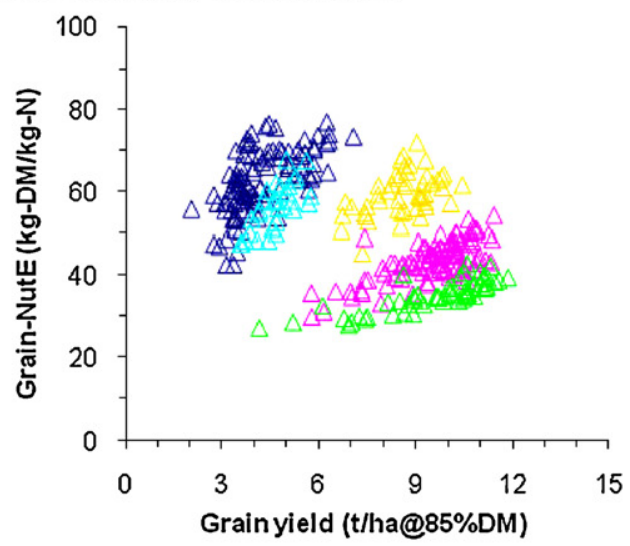

(3e) Grain-NutE vs. Total N-uptake

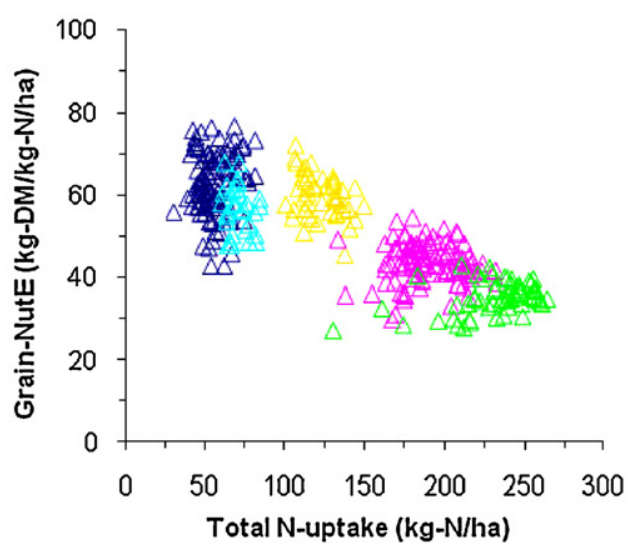

(3f) Grain-NutE vs. Grain \%N

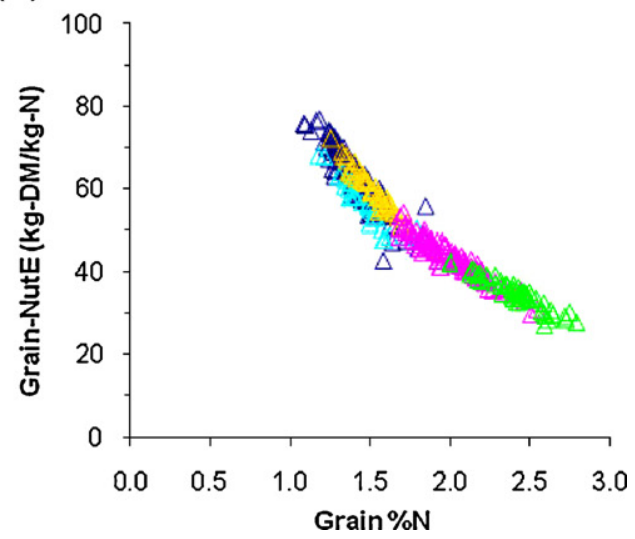

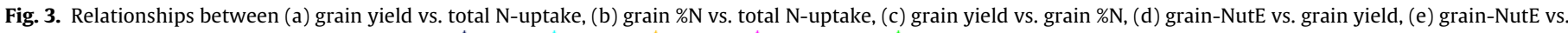
total N-uptake, (f) grain-NutE vs. grain \%N at N0 $(\Delta), \mathrm{N} 50(\Delta), \mathrm{N} 100(\Delta), \mathrm{N} 200(\Delta)$, and $\mathrm{N} 350(\Delta)$. Data points are for individual years.

small doses during the period of rapid crop growth (period of high $\mathrm{N}$ demand) rather than as a single large dose at the beginning of rapid crop growth, then losses are minimised and crop recovery is maximised. Unfortunately, multiple applications may not be economic for many farmers.

Efficient capture of nitrate from the topsoil requires a high rooting density. Given favourable soil conditions, winter wheat has one of the most rapidly growing and prolific root systems of all arable crops (Barraclough et al., 1991). The scope for further improving this trait may not be very great in wheat. In the subsoil, roots capture nitrate residues leached during previous cropping cycles. Sowing crops early can help to promote deep rooting and the capture of subsoil $\mathrm{N}$ (and water), but a major limitation to deep rooting (and all root growth) is mechanical impedance caused by compacted soils (plough-pans) and dense sub-soils (Barraclough et al., 1991; Clark et al., 2003). This may prove difficult to overcome by genetic means alone as the growth pressure that roots can exert is ultimately constrained by a physiological ceiling. There is anecdotal evidence that dicotyledon roots can act as 'physiological ploughs' and grow through plough-pans and dense soils, but Clark and Barraclough (1999) found no difference in maximum root growth pressure between monocotyledons and dicotyledons. Deep rooting can become self-sustaining as deep roots generate cracks for subsequent root growth as they dry-out the soil. The prosaic solution to this problem is for farmers to ensure that soils never become compacted. 


\section{(4) Grain-NutE vs Grain Yield}

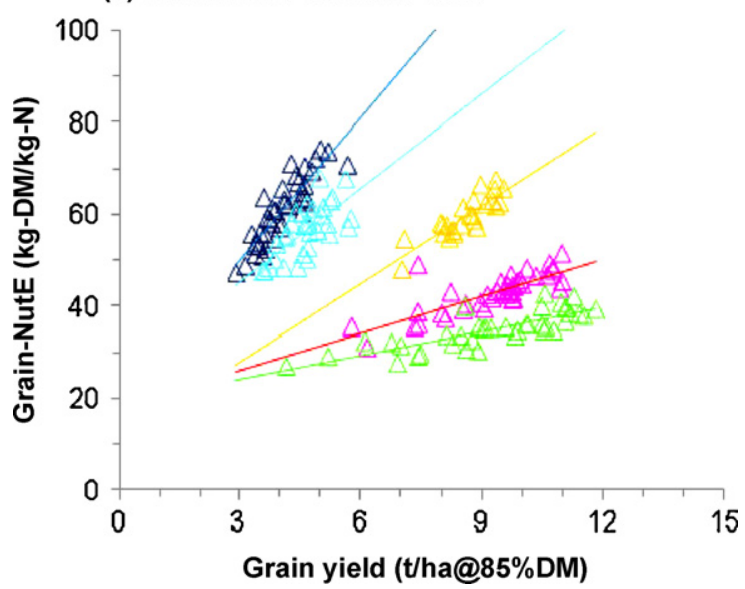

Fig. 4. Relationships between grain-NutE and grain yield at NO ( $\Delta$ ), N50 ( $\triangle$ ), N100 $(\triangle)$, N200 $(\triangle)$, and N350 $(\triangle)$. Data points are means over years. The regression line parameters $(y=\underline{m} x+\underline{c})$ are: $m=10.40,6.83,5.69,2.67$ and $1.74 ; c=18.42,24.45$, $10.67,18.18$ and $18.91 ; R^{2}=0.77,0.50,0.75,0.64$ and 0.67 at N0 $(\Delta), \mathrm{N} 50(\triangle), \mathrm{N} 100$ $(\triangle)$, N200 $(\triangle)$, and N350 $(\triangle)$, respectively.

The present study demonstrated substantial genetic variation in grain-NutE among short-straw wheat varieties with the best outperforming the worst by $24-42 \%$ depending on N-rate. The present results also confirmed a strong correlation between grain-NutE and grain yield with up to $77 \%$ of the variation in grain-NutE, depending on $\mathrm{N}$-rate, being accounted for by variation in yield. So, most of the variation in grain-NutE can be ascribed to improvements in grain yield, but there were 'outliers' in the relationships exhibiting greater grain-NutE than might be expected for their yield. Such varieties merit further investigation. There was a reasonable correlation between rankings at high and low $\mathrm{N}$ indicating that good performers at high-N were often good at low-N. There was no correlation between grain-NutE and total-Nup at individual $\mathrm{N}$-rates, indicating scope for independently improving these traits.

What are the constraints to improving grain-NutE? Grain-NutE is yield per unit of N-uptake, so either yield must be increased at fixed $\mathrm{N}$-uptake as happened with the short-straw varieties, or yield must be maintained with less uptake. In either case, grain \% $\mathrm{N}$ will suffer unless NHI can be increased as the parameters are related as follows:

$$
\begin{aligned}
\text { Nitrogen harvest index }(\mathrm{NHI}) & =\frac{\text { grain-Nup }}{\text { total-Nup }} \\
& =\frac{\text { grain-yield } \times \text { grain- } \% \mathrm{~N}}{\text { total-Nup }} \\
& =\text { grain-NutE } \times \text { grain- } \% \mathrm{~N}
\end{aligned}
$$

There are four key variables determining $\mathrm{N}$-efficiency in a wheat crop - grain yield, grain \% $\mathrm{N}$, total $\mathrm{N}$-uptake and $\mathrm{NHI}$ - and the relationships between these variables and grain-NutE are constrained by the law of conservation of matter. This simple mass-balance law, i.e. matter cannot be created or destroyed, is a special case of the $1 \mathrm{st}$ Law of Thermodynamics. The constraints on grain-NutE imposed by this law can be calculated with an algorithm as demonstrated in Table 6.

Consider a crop yielding $10 \mathrm{t} /$ ha of grain (100\% DM) with a total $\mathrm{N}$-uptake of $250 \mathrm{~kg}-\mathrm{N} / \mathrm{ha}$, a grain-N of $2 \%$, and a $\mathrm{NHI}$ of $80 \%$, which gives a grain-NutE of $40 \mathrm{~kg}-\mathrm{DM} / \mathrm{kg}-\mathrm{N}$ (line 2 in Table 6 ). For the same total uptake and NHI, yield and hence grain-NutE can only be improved if grain \% $\mathrm{N}$ falls to $1.82 \%$ (line 1 ). To improve grain-NutE whilst maintaining grain $\% \mathrm{~N}$ at $2 \% \mathrm{~N}$ with the same total $\mathrm{N}$-uptake of $250 \mathrm{~kg}-\mathrm{N} / \mathrm{ha}$ requires that NHI be increased to $88 \%$ (line 4). Yield can be maintained with a reduced uptake, in which case grain-NutE is increased, but again only at the expense of grain \%N which must fall to $1.6 \% \mathrm{~N}$ (line 8 ).

Whilst increasing NHI may be possible in theory, in practice the physiological processes leading to enhanced yield or enhanced grain \% $\mathrm{N}$ are mutually exclusive according to the 'selfdestruct' hypothesis of Sinclair and De Wit (1975). High grain yields (of starch) depend on continuing canopy photosynthesis which requires that a minimum concentration of catalytic leaf $\mathrm{N}$ (as Rubisco) be maintained. When $\mathrm{N}$ is required for grain protein, and root uptake has all but ceased, then $\mathrm{N}$ will be remobilised from leaves and stems (thereby increasing $\mathrm{NHI}$ ) which in turn will reduce photosynthesis and starch yield. This may be too simplistic, especially where Rubisco-N is present in super-critical amounts. Clearly, the transfer of any superfluous catalytic-N or non-catalytic-N (nonphotosynthetic) from leaves and stems would allow a simultaneous increase in NHI and grain starch yield. In this respect, timing and spatial patterns of senescence and remobilisation will influence NHI and yield.

The inverse relationship between grain yield and grain \% $\mathrm{N}$ when varieties or environments are compared is well established (Lawes and Gilbert, 1857; Kramer, 1979; Oury et al., 2003). When N supply is the main variable, the relationship takes on a more complex hyperbolic form with grain \% $\mathrm{N}$ at first decreasing with increasing yield (increasing $\mathrm{N}$ supply) before both yield and grain \% $\mathrm{N}$ increase with increasing $\mathrm{N}$ supply (Lopez-Bellido et al., 2004). These relationships are a direct result of the law of conservation of matter; high yields of high-quality grain (high grain $\% \mathrm{~N}$ ) need high inputs and high uptakes of nitrogen.

There is scope for genetically improving nitrogen recovery and utilization, but the law of conservation of matter ultimately sets a limit on crop $\mathrm{N}$ requirements. For example, if a farmer wanted to grow $12 \mathrm{t} /$ ha of good quality bread wheat (that is $10.2 \mathrm{t} / \mathrm{ha} @$ $100 \%$ DM with $2.3 \%$ grain-N), then $235 \mathrm{~kg}-\mathrm{N} / \mathrm{ha}(10.2 \mathrm{t} / \mathrm{ha} \times 2.3 \%)$ will be present in the grain alone. Assuming a NHI of $80 \%$, then another $60 \mathrm{~kg}-\mathrm{N} / \mathrm{ha}$ will be present in the straw which gives a

Table 6

\begin{tabular}{|c|c|c|c|c|c|c|c|}
\hline & N-up total (kg-N/ha) & $\mathrm{N}$-up grain (kg-N/ha) & $\mathrm{N}$-up straw (kg-N/ha) & NHI (\%) & Yield grain (t/ha) & $\mathrm{N}$ grain (\%) & NutE grain $(\mathrm{kg} / \mathrm{kg})$ \\
\hline 1 & 250 & 200 & 50 & 80 & 11 & 1.82 & 44 \\
\hline 2 & 250 & 200 & 50 & 80 & 10 & 2.00 & 40 \\
\hline 3 & 250 & 200 & 50 & 80 & 9 & 2.22 & 36 \\
\hline 4 & 250 & 220 & 30 & 88 & 11 & 2.00 & 44 \\
\hline 5 & 250 & 220 & 30 & 88 & 10 & 2.20 & 40 \\
\hline 6 & 250 & 220 & 30 & 88 & 9 & 2.44 & 36 \\
\hline 7 & 200 & 160 & 40 & 80 & 11 & 1.45 & 55 \\
\hline 8 & 200 & 160 & 40 & 80 & 10 & 1.60 & 50 \\
\hline 9 & 200 & 160 & 40 & 80 & 9 & 1.78 & 45 \\
\hline
\end{tabular}

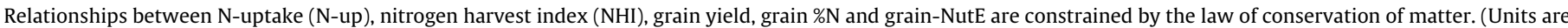
expressed on a dry matter basis.). 
total crop uptake ( $\mathrm{N}$ requirement) of $295 \mathrm{~kg}-\mathrm{N} / \mathrm{ha}$ (note that no allowance has been made for $\mathrm{N}$ in the roots). Assuming $60 \mathrm{~kg}$ $\mathrm{N} / \mathrm{ha}$ of soil-N-min is available and that this is recovered with $100 \%$ efficiency (Section 4.1.3), then to meet the remaining crop requirement of $235 \mathrm{~kg}-\mathrm{N} / \mathrm{ha}$, a fertiliser application of $390 \mathrm{~kg}-\mathrm{N} / \mathrm{ha}$ would be needed if fertiliser- $\mathrm{N}$ is recovered with just $60 \%$ efficiency (Section 4.1.3, but typical in the UK). If less than $390 \mathrm{~kg}-\mathrm{N} / \mathrm{ha}$ is applied, then under these conditions, $12 \mathrm{t} /$ ha of grain at $2.3 \% \mathrm{~N}$ would not be attainable unless the recovery efficiency could be improved.

\section{Conclusions}

The crop variables grain yield, grain \%N, total N-uptake, nitrogen utilization efficiency for grain (grain-NutE), grain harvest index $(\mathrm{GHI})$ and nitrogen harvest index (NHI) were affected to different extents by the experimental factors 'N-rate' $(N)$, 'Year' $(Y)$ and 'Variety' $(V)$. 'N-rate' had the greatest effect on grain yield, grain \% $\mathrm{N}$, total $\mathrm{N}$-uptake and grain-NutE. 'Year' had the greatest effect on GHI and NHI. 'Variety' generally had the least effect of the three factors, but there were significant varietal differences in all six crop variables. Differences were particularly marked between 'tall' and 'short' varieties, but were also present between 'short' varieties. In the case of grain-NutE, the best short varieties out-performed the worst by $24-42 \%$ depending on $\mathrm{N}$-rate. Up to $77 \%$ of the variation in grain-NutE, depending on N-rate, was accounted for by yield, but 'outliers' in this relationship offer scope for genetic improvement independently of yield. All interactions between the factors were highly statistically significant $(0.1 \%)$ for all variables, but only the 2-way interaction, $Y \times N$, made an important contribution to variation. There was a particularly strong $V \times N$ interaction in the case of total N-uptake, but not for grain-NutE. Total N-uptake and grain-NutE were not correlated. There was a near-functional inverse relationship between grain-NutE and grain \%N. Highquality bread wheat (high grain \%N) can be expected to have a low grain-NutE.

The four key variables determining N-efficiency in a wheat crop - grain yield, grain \% $\mathrm{N}$, total $\mathrm{N}$-uptake and $\mathrm{NHI}$ - are ultimately constrained by the law of conservation of matter. Improving grain-NutE at a given total $\mathrm{N}$-uptake and $\mathrm{NHI}$ can only be achieved at the expense of grain \%N. For a given total Nuptake, grain yield (and hence grain-NutE) can only be increased whilst simultaneously maintaining grain \% $\mathrm{N}$ if $\mathrm{NHI}$ is increased. In practice, simultaneously increasing $\mathrm{NHI}$ and grain starch yield may be difficult because the two processes are mutually exclusive. The transfer of non-catalytic (non-photosynthetic) $\mathrm{N}$ from leaves and stems would allow a simultaneous increase in $\mathrm{NHI}$ and grain starch yield. The law of conservation of matter ultimately sets a limit on all physiological and agronomic processes that determine crop $\mathrm{N}$ requirements. A high yield of highquality grain (high grain $\% \mathrm{~N}$ ) requires a high input and uptake of nitrogen.

\section{Acknowledgements}

Rafael Lopez-Bellido would like to thank Junta de Extremadura (Consejeria de Educacion, Ciencia y Tecnologia-Fondo Social Europeo) for financial support. This work was part-funded by DEFRA (Department for the Environment, Food and Rural Affairs: www.defra.gov.uk) as a component of the WGIN project (Wheat Genetic Improvement Network: www.wgin.org.uk). Rothamsted Research (www.rothamsted.ac.uk) receives grant-aided support from the BBSRC (Biotechnology and Biological Sciences Research Council: www.bbsrc.ac.uk).

\section{References}

Addiscott, T.M., Powlson, D.S., 1992. Partitioning losses of nitrogen fertilizer between leaching and de-nitrification. Journal of Agricultural Science, Cambridge 118, 101-107.

Austin, R.B., 1999. Yield of wheat in the United Kingdom: recent advances and prospects. Crop Science 39, 1604-1610.

Austin, R.B., Ford, M.A., Edrich, J.A., Blackwell, R.D., 1977. The nitrogen economy of winter wheat. Journal of Agricultural Science, Cambridge 88, 159-167.

Austin, R.B., Bingham, J., Blackwell, L.T., Evans, L.T., Ford, M.A., Morgan, C.L., Taylor, M., 1980. Genetic improvements in winter wheat yields since 1900 and associated physiological changes. Journal of Agricultural Science, Cambridge 94 675-689.

Avery, B.W., Bullock, P., 1969. Morphology and classification of Broadbalk soils. In: Rothamsted Experimental Station, Report for 1968, Part 2. Chapter 5, the Soils of Broadbalk. Lawes Agricultural Trust, Harpenden, UK, pp. 63-81.

Avery, B.W., Catt, J.A., 1995. The Soil at Rothamsted. Lawes Agricultural Trust, Harpenden, UK.

Barraclough, P.B., Kuhlmann, H., Weir, A.H., 1989. The effects of prolonged drought and nitrogen fertilizer on root and shoot growth and water uptake by winter wheat. Journal of Agronomy and Crop Science (Germany) 163, 352-360.

Barraclough, P.B., Weir, A.H., Kuhlmann, H., 1991. Factors affecting the growth and distribution of winter wheat roots under UK field conditions. In: McMichael, B.L., Persson, H. (Eds.), Plant Roots and their Environment. Elsevier Science, pp. 410-417.

Brancourt-Hulmel, M., Doussinault, G., Lecomte, C., Bérard, P., Le Buanec, B., Trottet M., 2003. Genetic improvement of agronomic traits of winter wheat cultivars released in France from 1946 to 1992. Crop Science 43, 37-45.

Clark, L.J., Barraclough, P.B., 1999. Do dicotyledons generate greater maximum axial root growth pressures than monocotyledons? Journal of Experimental Botany $50,1263-1266$

Clark, L.J., Whalley, W.R., Barraclough, P.B., 2003. How do roots grow in strong soil? Plant and Soil 255, 93-104.

Cox, T.S., Shroyer, J.P., Liu, B.H., Sears, R.G., Martin, T.J., 1988. Genetic improvement in agronomic traits of hard red winter wheat cultivars from 1919 to 1987. Crop Science 28, 756-760.

Dhugga, K.S., Waines, J.G., 1989. Analysis of nitrogen accumulation and use in bread and durum wheat. Crop Science 29, 1232-1239.

Dumas, J.B.A., 1831. Procedes de l'analyse organique. Annales de Chimie et de Physique 2, 198-213.

Fageria, N.K., Baligar, V.C., Li, Y., 2008. The role of nutrient efficient plants in improving crop yields in the twenty first century. Journal of Plant Nutrition 31 , $1121-1151$.

Fischer, R.A., 1981. Optimizing the use of water and nitrogen through breeding of crops. Plant and Soil 58, 249-278.

Fischer, R.A., Wall, P.C., 1976. Wheat breeding in Mexico and yield increases. Journal of the Australian Institute of Agricultural Science 42, 139-148.

Foulkes, J., Holdsworth, M., Kerr, S., Kightly, S., Barraclough, P., Hawkesford, M. Shewry, S., 2006. A study of the scope for the application of crop genomics and breeding to increase nitrogen economy within cereal and rapeseed based food chains. Final Report for Project AR0714. Defra, London.

Foulkes, M.J., Snape, J.W., Shearman, V.J., Reynolds, M.P., Gaju, O., Sylvester-Bradley, R., 2007. Genetic progress in yield potential in wheat: recent advances and future prospects. Journal of Agricultural Science 145, 17-29.

Good, A.G., Shrawat, A.K., Muench, D.G., 2004. Can less yield more? Is reducing nutrient input into the environment compatible with maintaining crop production? Trends in Plant Science 9, 597-605.

HGCA, 2009. HGCA Recommended List 2009/10 for Cereals and Oilseeds. HomeGrown Cereals Authority, London, England. www.hgca.com.

Hirel, B., Le Gouis, J., Ney, B., Gallais, A., 2007. The challenge of improving nitrogen use efficiency in crop plants: towards a more central role for genetic variability and quantitative genetics within integrated approaches. Journal of Experimenta Botany 58, 2369-2387.

Kramer, T., 1979. Environmental and genetic variation for protein content in winter wheat (Triticum aestivum L.). Euphytica 28, 209-218.

Lawes, J.B., Gilbert, J.H., 1857. On some points in the composition of wheat grain, its products in the mill and bread. Journal of the Chemical Society 10,1-55.

Le Gouis, J, Pluchard, P., 1996. Genetic variation for nitrogen use efficiency in winter wheat (Triticum aestivum L.). Euphytica 92, 221-224.

Le Gouis, J., Beghin, D., Heumez, E., Pluchard, P., 2000. Genetic differences for nitrogen uptake and nitrogen utilisation efficiencies in winter wheat. European Journal of Agronomy 12, 163-173.

Lemaire, G., Gastal, F., 2009. Quantifying crop responses to nitrogen deficiency and avenues to improve nitrogen use efficiency. In: Sadras, V.O., Calderini, D.F.(Eds.), Crop Physiology: Applications for Genetic Improvement and Agronomy. Academic Press, pp. 171-211.

Lopez-Bellido, R.J., Shepherd, C.E., Barraclough, P.B., 2004. Predicting post-anthesis $\mathrm{N}$ requirements of bread wheat with a Minolta SPAD meter. European Journal of Agronomy 20, 313-320.

MAFF, 2000. Fertiliser Recommendations for Agricultural and Horticultural Crops Reference Book 209, 7th Edition. Ministry of Agriculture, Fisheries and Food. The Stationery Office, London, UK. www.defra.gov.uk.

Moll, R.H., Kamprath, E.J., Jackson, W.A., 1982. Analysis and interpretation of factors which contribute to efficiency of nitrogen utilization. Agronomy Journal 74, 562-564 
NABIM, 2009. Wheat Guide. National Association of British and Irish Millers, London, UK. www.nabim.org.uk.

Novoa, B., Loomis, R.S., 1981. Nitrogen and plant production. Plant and Soil 58, $177-204$.

Ortiz-Monasterio, J.I., Sayre, K.D., Rajaram, S., McMahon, M., 1997. Genetic progress in wheat yield and nitrogen use efficiency under four nitrogen rates. Crop Science 37, 898-904.

Oury, F.X., Berard, P., Brancourt-Hulmel, M., 2003. Yield and grain protein concentration in bread wheat: a review and a study of multi-annual data from a French breeding program. Journal of Genetics and Breeding 57, 5968.

Powlson, D.S., Hart, P.B.S., Poulton, P.R., Johnston, A.E., Jenkinson, D.S., 1992. Influence of soil type, crop management and weather on the recovery of ${ }^{15} \mathrm{~N}$-labelled fertilizer applied to winter wheat in spring. Journal of Agricultural Science, Cambridge $118,83-100$.
Raun, W.R., Johnson, G.V., 1999. Improving nitrogen use efficiency for cereal production. Agronomy Journal 91, 357-363.

Recous, S., Fresneau, C., Faurie, G., Mary, B., 1988. The fate of labelled ${ }^{15} \mathrm{~N}$ urea and ammonium nitrate applied to a winter wheat crop. Plant and Soil 112, 205-224.

Shearman, V.J., Sylvester-Bradley, R., Scott, R.K., Foulkes, M.J., 2005. Physiological processes associated with wheat yield progress in the UK. Crop Science 45, 175-185.

Sinclair, T.R., De Wit, C.T., 1975. Photosynthate and nitrogen requirements for seed production. Science $189,565-567$.

Slafer, G.A., Andrade, F.H., 1991. Changes in physiological attributes of the dry matter economy of bread wheat (Triticum aestivum) through genetic improvement of grain yield potential at different regions of the world. A review. Euphytica 58, 37-49.

Van Sanford, D.A., MacKown, C.T., 1986. Variation in nitrogen use efficiency among soft red winter wheat genotypes. Theoretical and Applied Genetics 72, 158-163. 